\title{
A Case of Eosinophilic Gastritis with Gastric Bleeding
}

\author{
Dedy G. Sudrajat*, Hasan Maulahela** \\ *Department of Internal Medicine, Ciputra Hospital Citra Garden City, Jakarta \\ **Division of Gastroenterology, Department of Internal Medicine, \\ Faculty of Medicine, Universitas Indonesia/ \\ Dr Cipto Mangunkusumo General National Hospital, Jakarta
}

\section{Corresponding author:}

Hasan Maulahela. Division of Gastroenterology, Department of Internal Medicine, Dr. Cipto Mangunkusumo General National Hospital. Jl. Dipoenegoro No. 71 Jakarta Indonesia. Phone: +62-21-3153957; facsimile: +62-21-3142454.E-mail: hasan.maulahela@yahoo.com

\begin{abstract}
Eosinophilic gastritis is a manifestation of gastrointestinal eosinophilic disease. The clinical symptoms are not specific, similar to other gastric disease complaints. The diagnostic aproach aside from clinical manifestations is also from endoscopic and histopathological features as the gold standard. Management includes drugs and diet. In some cases with strictures and perforations, endoscopic or even surgical intervention needed. Steroidbased therapy, especially topical preparations, is still the main choice. Other alternative therapies such as immunosuppression and targeted therapy showed good results in several case reports and small-scale studies. Further research to get a better management needed, considering the prevalence of this disease is elevated.
\end{abstract}

Keywords: eosinophils, eosinophilic gastritis, gastric bleeding

\begin{abstract}
ABSTRAK
Penyakit eosinofilik gastritis merupakan salah satu manifestasi dari penyakit eosinofilik saluran cerna. Gejala klinisnya tidak spesifik, mirip dengan keluhan penyakit lambung lainnya. Pendekatan diagnostiknya selain dari keluhan klinis juga dari gambaran endoskopi dan histopatologi sebagai baku emas. Tatalaksananya mencakup medikamentosa dan diet. Pada beberapa kasus dengan striktur dan perforasi memerlukan intervensi endoskopi atau bahkan bedah. Terapi berbasis steroid, utamanya dipilih sediaan topikal, masih merupakan pilihan utama. Alternatif terapi lain seperti immunosupresn dan terapi target memberikan hasil yang cukup baik pada beberapa laporan kasus dan penelitian skala kecil. Penelitian lebih lanjut untuk memberikan tatalaksana yang semaikin baik diperlukan seiring makin meningkatnya prevalensi penyakit ini.
\end{abstract}

Kata kunci: eosinofil, gastritis eosinofilik, perdarahan lambung

\section{INTRODUCTION}

Eosinophilic Gastrointestinal diseases (EoGID) has characteristics of eosinophil infiltration in gastrointestinal tissue, resulting in morphological and functional abnormalities of the gastrointestinal tract. ${ }^{1}$ The clinical manifestations may be eosinophilic esophagitis (EoE) or non EoE GID which consist of gastritis, gastroenteritis, enteritis, or colitis. ${ }^{2}$ The prevalence of eosinophilic gastritis was 6.3/100000, associated with allergic diseases and often have concurrent drug allergies, rhinitis, asthma, sinusitis, dermatitis, food allergies, eczema, or urticaria. ${ }^{3}$

\section{CASE REPORT}

32-year-old woman, coming with complaints of frequent nausea and vomiting. It felt since the last 6 
months, felt at any time, not related to eating schedules. Epigastric pain is also often felt. Fever is not felt. Weight loss of $3 \mathrm{~kg}$ in the last 3 months. So far, there are no specific diseases and no routine medication taken. There is no drug allergy, food or intolerance. Several times came to the general practitioner given PPI and antacids. Complaints decrease but often reappear. The patient finally came to the Cipto Mangunkusumo Hospital, Gastroenterology Clinic. Blood tests showed anemia $(10.6 \mathrm{mg} / \mathrm{dL})$. Patients performed esophagogastroduodenoscopy. Obtained picture of erosive pangastritis. In the fundus looks prominent with blood seepage also visible. Biopsy was carried out in several parts. Anatomical pathology results showed that lamina propria was partially swollen due to acute and chronic inflammatory cells. Eosinophils found 25-30/LPB. Mild gland atrophy appears. Not found intestinal metaplasia and helicobacter pylori, the conclusion is a eosinophilic gastritis. Patients were given treatment with methylprednisolone 32 $\mathrm{mg}$ /day (divided dose), lansprazole $2 \times 30 \mathrm{mg}$, and $3 \times 15 \mathrm{cc}$ sucralfate. After 2 weeks of clinical evaluation. The patient feels a significant improvement. Nausea and vomiting are much reduced. Occasionally it still appears if you eat a little spicy and fatty. We dicedid to tapper off methylprednisolone. In subsequent evaluations complaints are sometimes still repeated with a frequency that is less frequent (2-4 times in 2-3 months). Gastroscopy plans to repeat 2 months from the initial examination.

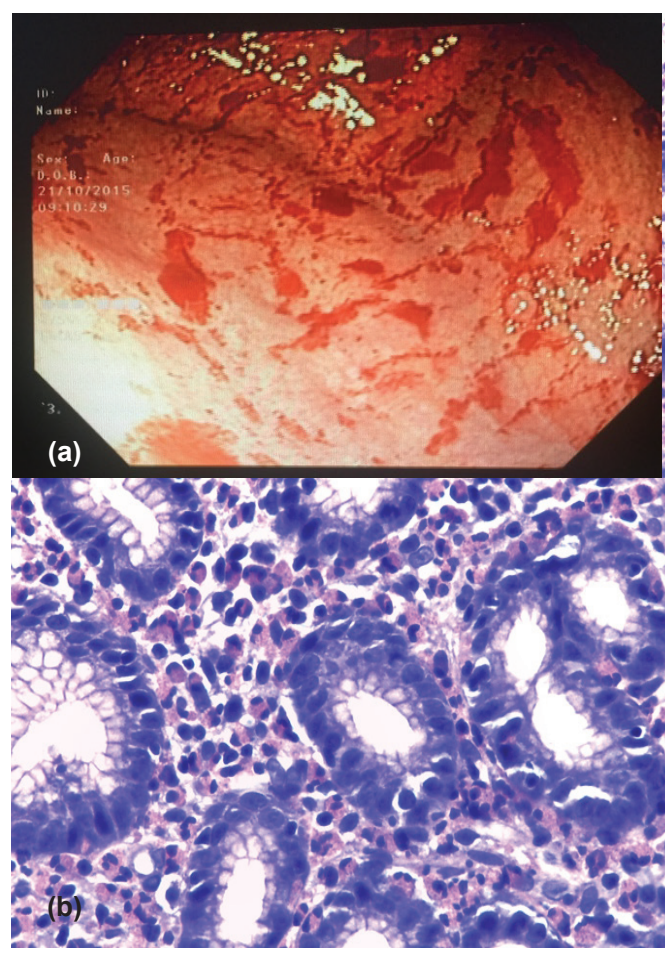

Figure 1. (a) Endoscopy finding; (b) Histological finding)

\section{DISCUSSION}

The role of genetics and the environment is thought to have a role in the formation of this disease. Family clusters are reported in the West and studies of monozygotic and dizygotted twins show the role of genetic factors that are important in their development although their contribution is only $20 \% .^{1,4}$ In Japan, there are no known cases of family clusters. It is assumed that genetic factors are not strong enough to affect patients in Japan. ${ }^{1}$ In this case, patient denied that any member of her family have a similar disease.

Th2 response and increased permeability of the esophageal mucosa are the main abnormalities found in EoE cases. This increased permeability results in the entry of food and allergens into subepithelial tissue and triggers allergic reactions following eosinophil infiltration. This condition is also aggravated by the presence of gastric acid reflux which will damage the esophageal epithelium thereby increasing the intercellular space and epithelial permeability. This explains the data that the incidence of EoE is also related to an increase in levels of gastric acid secretion. Eotaxin is a chemokine in the digestive tract. Eotaxin 3 in particular was found to have increased expression in EoEGID. ${ }^{4,5}$

Several studies have obtained data on the presence of several identified environmental risk factors. The high proportion of EoE patients with atopy, triggers the focus of research focus on the relationship of atopy with EoEGID. ${ }^{1,4}$ Several studies identified a variety of microbiota and patterns of relationship with atopic disease. Microbiota differences in healthy individuals with GERD and EoEGID patients have been found in the study. The number of bacteria increases in EoEGID and GERD compared to healthy people. Haemophillus microbiota significantly increased in untreated EoE patients, whereas in GERD the streptococcus population increased. Cesarean delivery, care at the NICU, enteral food choices, and especially the use of antibiotics in neonates, are important because they can change the composition of the microbiota ${ }^{1,4,6}$. The use of stomach acid suppressants can increase gastrointestinal permeability. The study found that increasing permeability can inhibit protein digestion and this triggers the IgE formation response. Studies in pregnant women obtain data that the use of PPIs is associated with an increased risk of atopy in the mother and fetus. Patient denied any history of allergy and she was take PPI only since 3 months after felt naussea and vomiting. 
The relationship between pylori infection with several atopic conditions such as allergic rhinitis, asthma, and atopic dermatitis has been found in a study. This was also found to be related to EoE in both children and adults, where the risk of EoEGID decreased with the presence of $\mathrm{H}$. pylori infection. The control group showed significantly higher seroprevalence than $H$. pylori $(37.9 \%, \mathrm{p}<0.0001)$ when compared with patients with EoE. EoE is inversely related to $\mathrm{H}$. pylori infection $\left[\mathrm{OR}=0.24 ; 95 \% \mathrm{CI}\right.$ : 0.11-0.50). ${ }^{4,7}$

In eosinophilic diseases of the gastrointestinal tract can have symptoms of abdominal pain, bloating, and gastrointestinal bleeding. Nausea, vomiting, reflux, and full satiety can occur in eosinophilic gastritis. ${ }^{8}$ Symptoms tend to be recurrent and chronic. Iron deficiency anemia, malabsorption, and failure to thrive in children can be found. The patient in this case also have anemia. Symptoms of obstruction, pyloric stenosis, and gastric outlet obstruction can occur in cases where eosinophil infiltration causes thickening of the muscular mucosal wall..$^{3,5}$ In a case series from Australia eosinophilic gastroenteritis was initially misdiagnosed as functional dyspepsia. Blood eosinophil counts can be normal, although studies from the Mayo Clinic suggest that most patients $(80 \%)$ have at least mild peripheral eosinophilia. ${ }^{3}$ In this patient the blood eosinophil counts also normal.

In patients with eosinophilic gastroenteritis, endoscopic findings might appear to be normal, but erythema, white specks, focal erosions, ulcerations, fold thickening, polyps, nodules, and friability have all been described.(wagner) Other features may include white exudates, micro abscesses, muscular rings, obstruction of food scraps. ${ }^{5,9}$ In eosinophilic gastroenteritis, micronodules are found on endoscopy, and these lesions often contain lymphocyte and eosinophil clots. ${ }^{5}$

Histology of gastrointestinal mucosal biopsies is the gold standart for diagnosis. ${ }^{3}$ Biopsy must be taken from 5-6 locations in each segment involved and although in rough appearance no abnormalities are seen. The most common benchmarks are 30 eosinophils / lpb in the stomach and 50 eosinophils in the duodenum and colon. ${ }^{8}$ Certain glandular layers, eosinophils in abscesses, mucosal thickening, basal cell hyperplasia, dilatation of intercellular spaces, increasing the likelihood of eosinophilic gastroenteritis. ${ }^{8,10}$ Staining with monoclonal antibodies for human eosinophilic major basic proteins can provide a higher number of eosinophilic found (mean 109.6 vs. 80.6; $p<0.001$ ).$^{11}$

Multiply food allergy test with serum IgE or skin test. The majority of patients with EoEGID have the sensitivity of the test. Patch tests for atopy detection are not recommended as a routine check. ${ }^{10}$

The goal of therapy is not only to reduce clinical symptoms but also prevent the progression of the disease and complications. Another parameter that can be measured is the improvement of the histological picture $(<15 \mathrm{eos} / \mathrm{lpb}) .{ }^{12}$ Some report concluded that roton-pump inhibitors (possibly through inhibition of eotaxin) can improve the symptoms. However, the improvement in symptoms in functional dyspepsia with these or other therapies is not proven to occur through the stabilisation or reduction of eosinophil numbers. Patients who respond to PPI are around $60 \%$. Of the groups that did not respond to PPI, they showed a response with vonoprazan (Potassium competitive acid blocker). ${ }^{3,13}$

Dietary therapy is recommended as a first-line treatment for eosinophilic gastrointestinal disorders. (walker) Diet by avoiding specific allergens is quite effective but often difficult to do because eliminating one component in food is not an easy matter considering often the content that must be avoided is in every food and snacks that are commonly available. Two ingredients that are often the trigger factors are wheat and milk, so often these 2 things are recommended to be avoided in the patient's diet. It was also identified that these 4 foodstuffs were also effective in triggering histological remissions if not consumed, namely soybeans, eggs, beans, and seafood. ${ }^{1,10}$

Corticosteroids are used as first-line drug therapy. Oral prednisone at doses of $20-40 \mathrm{mg}$ per day for 2 weeks has been shown to induce clinical remission in most patients, although higher doses $(0 \cdot 5-1 \mathrm{mg} /$ $\mathrm{kg}$ ) are suggested in some reports. In this case we used $32 \mathrm{mg}$ /day of methylprednisolone. Maintenance doses $(5-10 \mathrm{mg} /$ day) sometimes needed in relapse case. However, because of the undesirable long-term sideeffects of systemic corticosteroid therapy, agents with less propensity to reach the systemic circulation might be considered as alternatives. ${ }^{3}$ Topical corticosteroids such as fluticasone and budesonide are the treatment of choice. Fluticasone inhaler but swallowed and budenosine respule mixed with artificial sweetener to form a thick liquid which is then swallowed. Fluticasone dose $400-800 \mathrm{mcg} /$ day or $880-1760 \mathrm{mcg} /$ day in 2-4 divided doses for 6-8 weeks. Whereas Budesonide $2 \mathrm{mg}$ /day in divided doses. ${ }^{1,10}$ Systemic corticosteroids are not recommended for the long term but can be used to achieve symptom improvement and inflammation. Oesophageal candidiasis is found in 


\section{$5-30 \%$ of patients after topical steroid therapy. ${ }^{10}$}

Montelukast, a D4 receptor antagonist leukotrient, in the RCT study after topical steroid therapy, showed unfavorable results where although there were $40 \%$ of patients who remained in remission after 26 weeks but this did not differ significantly from plasebo. ${ }^{14}$ The RCT study used chemoattractant receptor-homologous molecule on Th2 cells (CRTh2) antagonist (OC000459) for 8 weeks, decreased eosinophil counts by an average of 40/1pb and decreased disease activity. ${ }^{12,15}$ Mepolizumab works to bind and inactivate IL-5 and show effectiveness in reducing eosinophil counts in EoE patients in studies Double blind RCT, but minimal clinical improvement. ${ }^{16}$ Infliximab $5 \mathrm{mg} / \mathrm{kgBB}$ did not show improvement in symptoms, eosinophil counts, and expression of alpha TNF in studies of 3 patients, but in other study report that infliximab and adalimumab had a positive result. ${ }^{3,12}$ Azathioprine was reported to be effective in the case series of 3 EoE patients with steroid dependent. ${ }^{3,10}$ Monoclonal antibodies targeting IL-13 (QAX576), given every 4 weeks for 8 weeks on a placebo RCT with 23 adult patients. The study showed a decrease in eosinophils by $60 \%$ compared to placebo, which rose by $23 \%$. RPC4046, a selective monoclonal antibody for IL-13, given weekly to 99 adult patients for 16 weeks shows a reduction in the number of eosinophils by $79 \%$ and a significant improvement in endoscopic features. ${ }^{12}$, 17 Surgical therapy and endoscopic intervention are carried out in cases that require esophageal dilatation or a perforation case. ${ }^{10}$

Eosinophilic Gastrointestinal disease is a chronic inflammatory disease where there is infiltration of eosinophils in the gastrointestinal tract leading to organ dysfunction. The underlying pathophysiology is an immune reaction triggered by food antigens in which there is an association with genetic markers related to Th2. Current treatments include medical and dietary management to prevent recurrence.

\section{REFERENCES}

1. Kinoshita Y, Oouchi S, Fujisawa T. Eosinophilic gastrointestinal diseases - Pathogenesis, diagnosis, and treatment. Allergology International 2019;68:420-9.

2. Gonsalves N. UpToDate [serial online]. Uptodate.com. 2020 [cited 2020 June 15]. Available from: https://ww.uptodate. com/contents/eosinophilic-gastroenteritis.

3. Walker M, Potter M, Talley N. Eosinophilic gastroenteritis and other eosinophilic gut diseases distal to the oesophagus. The Lancet Gastroenterology \& Hepatology 2018;3:271-80.

4. Jensen E, Dellon E. Environmental and infectious factors in eosinophilic esophagitis. Best Practice \& Research Clinical Gastroenterology 2015;29:721-9.
5. Jawairia M, Shahzad G, Mustacchia P. Eosinophilic Gastrointestinal Diseases: Review and Update. ISRN Gastroenterology 2012;2012:1-8.

6. Harris J, Fang R, Wagner B, Choe H, Kelly C, Schroeder S, et al. Esophageal Microbiome in Eosinophilic Esophagitis. PLOS ONE 2015;10:e128346.

7. von Arnim U, Wex T, Link A, Messerschmidt M, Venerito $\mathrm{M}$, Miehlke $\mathrm{S}$ et al. Helicobacter pyloriinfection is associated with a reduced risk of developing eosinophilic oesophagitis. Aliment Pharmacol Therapeutics 2016;43:825-830.

8. Cianferoni A. Eosinophilic esophagitis and other eosinophilic disorders of the gastrointestinal tract. Pediatric Allergy and Immunology 2020;31:25-27.

9. Parmar C, Attwood S. Emerging clinical evidence in the treatment of eosinophilic esophagitis. Clinical Investigation 2012;2:527-35.

10. DynaMed, Ipswich (MA): EBSCO Information Services. 1995 - Record No. T435297, Eosinophilic Esophagitis in Adults. [serial online] [cited 2020 June 19]. Available from https:// www.dynamed.com/topics/dmp $\sim$ AN $\sim$ T435297. Registration and login required.

11. Mueller S, Aigner T, Neureiter D, Stolte M. Eosinophil infiltration and degranulation in oesophageal mucosa from adult patients with eosinophilic oesophagitis: a retrospective and comparative study on pathological biopsy. J Clin Pathol 2006;59:1175-80.

12. Gonsalves N. Eosinophilic Gastrointestinal Disorders. Clinical Reviews in Allergy \& Immunology 2019;57:272-85.

13. Ishimura N, Ishihara S, Kinoshita Y. Sustained acid suppression by potassium-competitive acid blocker (P-CAB) may be an attractive treatment candidate for patients with eosinophilic esophagitis. Am J Gastroenterol 2016;111:1203-04.

14. Alexander J, Ravi K, Enders F, Geno D, Kryzer L, Mara K, et al. Montelukast does not maintain symptom remission after topical steroid therapy for eosinophilic esophagitis. Clin Gastroenterol Hepatol 2017;15:214-221.e2.

15. Straumann A, Hoesli S, Bussmann C, Stuck M, Perkins M, Collins L et al. Anti-eosinophil activity and clinical efficacy of the CRTH2 antagonist OC000459 in eosinophilic esophagitis. Allergy 2013;68:375-85.

16. DeVault K. Anti-interleukin-5 antibody treatment (mepolizumab) in active eosinophilic oesophagitis: a randomised, placebo-controlled, double-blind trial. Yearbook of Gastroenterology 2010;2010:11-12.

17. Hirano I, Collins M, Assouline-Dayan Y, Evans L, Gupta S, Schoepfer A, et al. RPC4046, a monoclonal antibody against IL13, reduces histologic and endoscopic activity in patients with eosinophilic esophagitis. Gastroenterology 2019;156:592-603.e10. 